\title{
Introduction: Law, Vulnerability, and Segregation: What Have We Learned from Ashley Smith's Carceral Death?
}

\section{Rebecca Bromwich and Jennifer M. Kilty}

\section{Introduction}

Ashley Smith's 2007 carceral death encountered widespread media attention. As time passed and the news cycle moved on to other fascinations, the details of her case started to fade from public discussion. As 2017 marks the ten-year anniversary of Smith's death, we felt it was time to re-examine and reflect upon different facets of the case. In the interests of clarity and for ease of reference, in the following pages we present a summary of some of the commonly understood and widely accepted facts of the case. Some of these commonly accepted "truths" are not unproblematic, as is discussed throughout the various entries in this special issue. We present these "facts of the case" to help ground the analyses and critiques presented in the manuscripts offered in this issue. ${ }^{1}$

\section{Case Summary}

Ashley Smith was a middle class, white, Canadian teen girl who died from selfstrangulation in an adult federal prison on October 19, 2007, at the age of nineteen. Smith was born January 29, 1988, in the province of New Brunswick and was adopted at five days old. It is widely reported that she experienced a "normal" childhood in Moncton, New Brunswick. During her early adolescence, Ashley started to get into trouble with various authorities and questions were raised about her mental health. Smith's parents report that at age thirteen or fourteen they saw distinct behavioural changes in their daughter. By age fifteen she had been before juvenile court fourteen times for various minor offences such as trespassing and causing a disturbance. In March 2002, Smith was assessed by a psychologist, who found no

1 This summary draws heavily on that set out in Rebecca Bromwich, Looking for Ashley: Re-Reading What the Smith Case Reveals about the Governance of Girls, Mothers and Families in Canada (Toronto: Demeter Press, 2015). See especially pages 6-9. Bromwich's book, and this summary, also draw on facts set forward in Smith (Re), 2013 CanLII 92762 (ON OCCO), Chief Coroner of Ontario, Inquest Touching the Death of Ashley Smith: Jury Verdict and Recommendations, December 2013, online: http://www.caefs.ca/wp-content/uploads/2014/01/A.S.-Inquest-JuryVerdict-and-Recommendations1.pdf; as well as New Brunswick Ombudsman and Child and Youth Advocate, Ashley Smith: A Report of the New Brunswick Ombudsman and Child and Youth Advocate on the Services Provided to a Youth Involved in the Youth Criminal Justice System by Bernard Richard (Fredericton: Office of the Ombudsman and Child and Youth Advocate, June 2008), http://www.cyanb.ca/images/AshleySmith-e.pdf, accessed June 1, 2015; and Correctional Investigator of Canada, "A Legacy of Missed Opportunities: The Case of Ashley Smith" by Howard Sapers (Edmonton: Office of the Correctional Investigator, 2011), online http://www.oci-bec. gc.ca/cnt/comm/sp-all/sp-all20111123-eng.aspx, accessed June 1, 2015.

Canadian Journal of Law and Society / Revue Canadienne Droit et Société, 2017,

Volume 32, no. 2, pp. 157-164. doi:10.1017/cls.2017.10 
evidence of mental illness. However, her behavioural problems continued and she was suspended from school numerous times during the fall of 2002. In March 2003, after a series of court appearances, Ashley was admitted to the Pierre Caissie Centre, a mental health centre, for assessment. She was diagnosed with various mental conditions, including "ADHD [(attention deficit and hyperactivity disorder)], learning disorder, borderline personality disorder and narcissistic personality traits" and was discharged early for unruly and disruptive behaviour. ${ }^{2}$

Ashley was first incarcerated as a youth at age fifteen, in 2003. She was initially sent to custody for a single offence, throwing crabapples at a postal carrier. There is no indication that anyone was injured by this act, but as her target was an agent of the state, the incident was taken very seriously. While Ashley had been in trouble for minor things before, like disobeying teachers and stealing a $\mathrm{CD}$, she had never spent time in custody. Her initial sentence for this offence was a period of one month in youth custody; during this sentence, she was quickly isolated in solitary confinement-misleadingly labelled by youth corrections as "therapeutic quiet time" - for what correctional officers determined to be disruptive behaviour on her first day in custody. While Smith's original sentence was a short one, as a result of the accumulation of hundreds of further convictions arising from disciplinary incidents, including those she received for self-harming, she remained in youth custody for three years.

In January 2006, Ashley Smith turned eighteen. On the same day, a motion was made under the Youth Criminal Justice Act (YCJA) by the Crown to transfer her to an adult facility. Smith retained a lawyer to fight the transfer, but was unsuccessful. On October 5, Smith was transferred to an adult federal prison-Nova Institution for Women, in Truro, Nova Scotia-where she spent the vast majority of her time in administrative segregation. The Correctional Service of Canada (CSC) differentiates administrative segregation (used to monitor prisoners deemed at risk of suicide or who engage in self-injurious behaviour) from disciplinary segregation (used as a form of punishment for institutional rule infractions), but this is a difference of status rather than the material conditions of confinement, as the cells and the types of deprivation prisoners experience are the same. These small cells include a metal cot, a thin suicide mattress and blanket (i.e., they do not tear and are fireproof), a metal sink and toilet and little else. Segregated prisoners are not permitted personal items and are typically given only a hospital gown to wear. They are housed in isolation for twenty-three hours a day, with one hour to shower and walk around an individually enclosed outdoor "yard," which means they have no access to programming or socialization beyond speaking to the guards who pass them food through the slot in their cell door.

While incarcerated in the adult federal prison system, Ashley was transferred a total of seventeen times between eight institutions across five provinces over a

New Brunswick Ombudsman and Child and Youth Advocate, Ashley Smith: A Report of the New Brunswick Ombudsman and Child and Youth Advocate on the Services Provided to a Youth Involved in the Youth Criminal Justice System by Bernard Richard (Fredericton: Office of the Ombudsman and Child and Youth Advocate, June 2008), http://www.cyanb.ca/images/AshleySmith-e.pdf, accessed June 1, 2015. 
period of eleven months The purpose of these transfers was to keep her in segregation past the legally prescribed limits. While in segregation, Smith was subject to repeated body cavity and strip searches and she was frequently tasered and peppersprayed. She was under the care of a series of psychiatrists, several of whom prescribed her a number of different psychotropic medications; she was sometimes given these drugs by force via involuntary injections. Smith was periodically given an opportunity to speak with a series of psychologists, but only through the food slot in her cell door. It has been widely reported that Ashley Smith suffered from very serious mental health issues that were never properly assessed and thus went untreated.

While in federal custody, Smith was disciplined hundreds of times and numerous new charges and convictions were imposed upon her as a result of disciplinary incidents within the carceral setting. Smith was involved in a myriad of reported "incidents" that figured prominently in daily SITREPS, or situation reports, that circulate to CSC management including regional authorities and bureaucrats at national headquarters in Ottawa. ${ }^{3}$ Correctional officers documented that Ashley self-injured and/or tied a ligature around her neck on at least 150 separate occasions, many of which were treated as disciplinary infractions. ${ }^{4}$ As her sentence lengthened due to these institutional infractions, Smith was never released from segregation and was held in youth and federal custody on a series of accumulating charges for four years. For long periods of time while in solitary confinement, Smith was not given soap, deodorant, adequate sanitary and menstrual supplies, or clean underwear, and she was also prohibited from having writing utensils or paper. To avoid physical confrontations with Smith, frontline staff were instructed not to enter her cell to remove the ligatures that she frequently tied around her neck until she had passed out. Dubbed the "wait and see" approach, this led to Ashley Smith dying in a hospital gown on the concrete floor of her segregation cell in Grand Valley Institution in Kitchener, Ontario, while several prison guards watched and videotaped her last moments from a few feet away in the hall outside her cell, not intervening or performing CPR for forty-five minutes as she lay dying before their eyes.

In 2011, four years after her death, the Smith family filed a wrongful death lawsuit against the Correctional Service of Canada for eleven million dollars. The suit was settled confidentially in May of 2011 for an undisclosed amount, and the warden of Grand Valley Institution for Women, where she died, was fired. Ashley Smith's death has been the subject of two coroner's inquests, or investigations, in the province of Ontario. The first was complex and involved many legal challenges as well as a change of coroner before it finally ended in a mistrial in September 2011. A new inquest into Smith's death began in September 2012 and concluded in December 2013 with a surprise verdict of homicide. ${ }^{5}$

In response to the homicide verdict, government actors and social reformers have been examining how the mentally ill, women in particular, can be better 
served by the prison system and how to limit the use of segregation in Canadian prisons. CSC released a report in December 2014 in which they claim to have already addressed the concerns raised by the 104 recommendations of the coroner's inquest. In this report, CSC rejects the recommendation to place limits on the use of segregation and rejects the further inquest recommendation that their management be independently overseen. Given CSC's refusal to make significant changes to their segregation practices, two provincial legal challenges have been raised regarding the use of indefinite segregation, the segregation for mentally ill prisoners, and the use of segregation as a response to self-injurious behaviour. The first lawsuit was jointly filed on January 19, 2015, by the British Columbia Civil Liberties Association and the John Howard Society of Canada against the Attorney General of Canada. One week later, the Canadian Civil Liberties Association and the Canadian Association of Elizabeth Fry Societies filed a similar petition in Ontario Superior Court. And in his 2015 Mandate letter to the new Minister of Justice, freshly elected Prime Minister Justin Trudeau tasked the Attorney General with addressing the problems revealed by the Smith case. To date, the Ashley Smith case remains unresolved in that a homicide verdict was entered while no individuals or institutions were officially blamed or held accountable for her death and no significant changes to carceral segregation practices as recommended by the coroner's inquest have been legally mandated.

\section{Special Issue Content: Implications of Ashley Smith's Case to Justice, Corrections, Pedagogy, and Feminist Analysis}

This special issue brings together a wide range of academic contributions from sociologists, criminologists, and socio-legal and development scholars that examine the Smith case from a variety of perspectives. While most of the manuscripts engage with traditional socio-legal scholarship, the special issue is broadly interdisciplinary and takes up the Smith case as an object lesson for thinking through different issues pertaining to girls' experiences of confinement. The articles contained herein offer a diverse range of critical perspectives and new ways to think about and make sense of what this case exemplifies and reveals about corrections, the gendered nature of punitive prison practices, girls' and women's criminalization, as well as the criminal law in Canada. Key themes that run throughout the issue relate to how gender, age, marginality, and vulnerability significantly affect how criminalized persons are treated, and a number of the contributors use these factors to theorize how criminalized women and girls might alternatively be understood and approached in and through law, sentencing, and corrections.

Debra Parkes's article specifically discusses the appalling misuse of solitary confinement against Ashley Smith while she was in correctional custody and considers the widespread abuse of solitary confinement (officially termed segregation in Canada) as constituting a human rights crisis. This article considers the role that litigation has already played, and might yet play, in curbing uses of solitary confinement in prisons in Canada and globally. Pertinent to this movement to end the use of isolation practices in carceral environments, her article considers the relationship of prisoner rights litigation to the broader abolitionist social movement, which she describes as an "abolitionist lawyering ethic." This provocative article is 
relevant for scholars, lawyers, advocates, and practitioners working in the penal abolitionist movement.

Lisa Kerr also looks at prison conditions as revealed by the Ashley Smith case. Kerr's article critically analyzes how prison conditions relate to sentencing aims. In her reading of caselaw to this effect, Kerr closely considers the implications of the fact that the Correctional Service of Canada (CSC), the nation's federal prison service, has refused to remedy the legislative and institutional shortcomings that caused the system failures that led to Smith's death. Kerr argues that these problematically common systemic failures should be taken into account by judges when making sentencing decisions. Specifically, she examines how judges fail to take into account the brutality of correctional practices and conditions of confinement when making sentencing decisions and suggests grounds on which they could do so. Kerr contends that sentencing determinations by judges in the youth and adult contexts often fail to consider how the harsh realities endemic to penal institutions affect the nature of the sentence and how it is experienced by those in custody. She proposes sentencing reform ideas that would expand doctrinal sentencing rules to enjoin judges to consider these effects of imprisonment when making sentencing determinations.

Gillian Balfour's article discusses the involvement of the Union of Canadian Correctional Officers (UCCO) in defending the three correctional officers initially charged with criminal negligence causing Ashley Smith's death. The author reviews statements made to media by the UCCO after Ashley's death, the UCCO's submissions to government review committees, and the agreement between the UCCO and the CSC regarding federally sentenced women. In her analysis of these communications and documents, Balfour contends that the UCCO shifted blame from the frontline correctional officers it represented to upper levels of CSC management for the system-wide failures to appropriately manage women's prisons that were linked to Smith's death. In an important critique of the power of correctional unions, the author argues that the UCCO's public narratives worked to bolster the legitimacy of extra-punitive uses of solitary confinement as a necessary strategy to manage "troubled young women" like Smith, whose "unmanageability" brings about unsafe working conditions for frontline correctional officers. In this way, the UCCO narrative refocuses attention on the risks involved for frontline correctional staff and away from their systemic mistreatment of Smith (and similarly situated prisoners) and effectively blames Smith for and legitimizes their use of extra-punitive methods of carceral management.

Elspeth Kaiser-Derrick's article considers the ways in which Ashley Smith's treatment resulted from and reinforced a problematic set of legal norms. The author views Smith's incarceration through the lens of legal pluralism afforded by the work of Martha-Marie Kleinhans and Roderick A. Macdonald and uses this framework to argue that, as a legal subject, Smith was an actor engaged in creating law in relationship with the laws and correctional norms governing her. While recognizing that Smith's status as a legal actor existed within the unequal power relations structuring the context of the system that broke her, Kaiser-Derrick argues that while the youth and adult federal correctional systems treated Smith as an excluded legal subject, there were ways that she was effectively a law-producer, 
capable of changing policy. In her innovative analysis, the author contends that the legal subject within a critical legal pluralism should be widened to encompass those who act within/against (and are acted upon by) legal/normative systems characterized by extreme power disparities. Kaiser-Derrick builds on and further develops Martha Fineman's influential vulnerability analysis by arguing that legal subjects who, like Ashley Smith, act within systems where they have little power should be understood and treated as vulnerable legal subjects. Seeing the vulnerability of these legal subjects provides a basis for institutions, including both the courts (in terms of sentencing) and corrections (in terms of treatment, programming and release), to be better attuned and more accurately responsive to their needs.

Carla Cesaroni and Michele Peterson-Badali also focus on Ashley Smith's vulnerability. Not only do the authors situate their manuscript within the corpus of their research scholarship on young adult development, they also write from their experience giving evidence as expert witnesses in the coroner's inquest into Smith's death, a legal process that is central to the legal and social scientific interpretations and understandings of the events that occurred in this particular case. They consider how Canada's correctional systems deal with young adults who have been criminalized in ways that are discordant with approaches taken in many reasonable comparator democratic countries across Europe. Instead of using the same punitive control strategies on youthful adults that are invoked across adult correctional settings, some European countries now recognize the young adult (aged eighteen to twenty-one) as experiencing a specific form of vulnerability and as having unique emotional and programming needs. Rooting their discussion in the developmental psychology scholarship that situates this age range as a distinct transitional period between adolescence and adulthood and paying special attention to gender, the authors propose an approach to the incarceration of young adults that differentiates their treatment from youth and from adults older than twenty-one. Considering the role of development is largely absent from socio-legal scholarship, this article offers an important line of inquiry that provides interesting terrain on which to reinvigorate debates on the detrimental effects of the forms of punishment (e.g., use of force, permanent/long-term segregation) to which Smith was subject. It is important to begin thinking through how these practices impede emotional and social development and how we can mobilize this information in terms of decarceration efforts.

Authors Charissa Crépault and Jennifer M. Kilty examine how the Smith case is interpreted and talked about via investigative journalism media accounts of the case. The authors employ an innovative methodological approach to narrative analysis to examine the coverage of this case on CBC's The Fifth Estate, which despite offering important critiques about the lack of adequate mental health care in federal prisons, they found to exhibit a palpable lack of a feminist narrative and/ or gendered analysis. The authors use the Smith case as a means to explicate feminist critiques of women's corrections and the ways they, and gendered analyses more broadly, continue to be sacrificed for gender neutral (or gender absent) evaluations. Deploying the conceptual technology of "through narrative," they discuss how The Fifth Estate's two episodes about Ashley Smith use monologues, interviews, and video images to construct coherent narratives about the case that sustain certain widely 
assumed ideas, especially medicalized notions about mental illness and the lack of mental health treatment in carceral settings. The authors also critique the documentaries' failures to consider the gendered nature of correctional practices and conclude that The Fifth Estate's reliance upon gendered stereotypes obfuscates how Ashley Smith's status as a "misbehaving" woman prisoner underwrote the brutality of her treatment.

Finally, Joanne Minaker's novel analysis considers a problematic related to, but a step removed from, the Ashley Smith case; rather than analysing the facts of Smith's life and death or how they have been or may be interpreted via the media or the courts, she examines how the case can be talked about and mobilized in the academy. In discussing how feminist pedagogy can inform teaching and learning about the Smith case, Minaker uses auto-ethnography to document how she teaches and engages in university level classroom discussions and how this case can be used pedagogically to help students gain deeper insight into social justice praxis, particularly efforts that involve girls and women. Minaker frames her pedagogical approach by way of what she describes as the 6Rs (i.e., root, risk, range, relationships, response, and respect) which she introduces when lecturing on "individual-level and structural-level pathways to girls' criminalization." She discusses how exploring Ashley Smith's case can be a way to provide students with opportunities to engage in their own critical theorizing and possible activism around broader social justice issues, especially those that are important to feminist criminological efforts. Minaker argues that this case provides a means to amplify feminist voices in the post-secondary classroom.

\section{Conclusion}

Ashley Smith died alone, having been brutally and illegally mistreated in adult federal prison and youth facilities for four years, despite never having committed a serious crime. No scholarship can change that. What is clear, however, is that what happened to her reflects a host of individual and systemic problems in Canada's criminal justice and correctional systems that have yet to be rectified. Taken together, the contributions compiled in this special issue reveal complex and manifold implications of studying the Ashley Smith case for Canadian penality in the present time. The diverse range of scholarship included in this issue discursively advocates for more humane, compassionate, and nuanced criminal justice efforts that are more sensitive to the particular needs of and structural oppressions facing women and girls who come into conflict with the law. More specifically, the articles contained in this volume evidence how ongoing examinations of this case position Smith's life and death as important and relevant for opening up new ways of understanding citizenship, inciting conversations about carceral abuses of power-especially in relation to the use of segregation/solitary confinementspurring social movements around women and girls unique needs, and inspiring law reform efforts as well as efforts to improve Canada's correctional and broader criminal justice systems.

It is of note that this special issue marks the ten-year anniversary of Ashley Smith's death. That her case remains relevant and a source for ongoing political debate, legal challenges, and advocacy and activism is telling of the swath of 
institutional and systemic failures to which this case attends, not to mention the slow pace of penal reform. The articles contained in this special issue speak to, and in many ways challenge, the taken-for-granted normative assumptions about the madness of criminalized women and girls and the forms of institutional security required to safely guard them. They also raise questions about the very nature of penal reform and the dangers of looking to existing institutions (be it law, corrections, or the media) to develop alternative and more humane approaches to penality. In guest editing this special issue, it was our hope that organizing this body of scholarship would provide the promise of and suggestions for ways to change how we talk about and deal with youth, corrections, gender, and criminalized women and girls. If these diverse manuscripts can contribute to ongoing discussions that help work towards institutional changes that recognize the loss of Smith's value as a human being and help ameliorate the conditions of confinement that criminalized people continue to experience in Canadian prisons, then it is our hope that this collection will have honoured her memory.

Rebecca Bromwich

Director, GDCR Program

Department of Law and Legal Studies

Carleton University

Rebecca.bromwich@carleton.ca

Jennifer M. Kilty

Associate Professor

Department of Criminology

University of Ottawa

jennifer.kilty@uottawa.ca 